\title{
EFEKTIVITAS PENGGUNAAN LINGKUNGAN SEBAGAI SUMBER BELAJAR MATERI IPA POKOK BAHASAN EKOSISTEM PADA KELAS VII SMP N 2 PRINGAPUS KABUPATEN SEMARANG TERHADAP HASIL BELAJAR SISWA
}

\author{
Miftakhul Jannah \\ Guru IPA SMP Negeri 2 Pringapus \\ Desa Jatirunggo Kecamatan Pringapus Kabupaten Semarang
}

\begin{abstract}
ABSTRAK
Pemanfaatan lingkungan sebagai sumber belajar diartikan suatu tempat mengajar yang menghadapkan peserta didik dengan benda-benda dan peristiwaperistiwa yang sebenarnya. Dengan demikian peserta didik dapat belajar secara nyata, tidak merasa bosan, mudah dimengerti dan diingat, serta pengkajian yang efektif dan lebih cepat, karena pemanfaatan lingkungan sebagai sumber belajar kontekstual mempunyai unsur-unsur yang membuatnya lebih baik dengan pembelajaran yang bersifat konvensional, diantaranya ceramah.

Penelitian ini bertujuan untuk mengetahui efektivitas pembelajaran IPA khususnya kelas VII menggunakan lingkungan langsung sebagai sumber belajar terhadap hasil belajar siswa kelas VII SMP N 2 Pringapus Kabupaten Semarang pada poko bahasan materi ekosistem. Hasil penelitian ini merupakan penelitian kuantitatif dengan metode penelitian eksperimen terpola bentuk posttest control design. Populasi dalam penelitian ini adalah peserta didik kelas VII SMP N 2 Pringapus Semarang, yaitu kelas VII A sebagai kelas eksperimen dan kelas VII C sebagai kelas kontrol. Pengumpulan data dalam penelitian ini menggunakan metode tes, observasi dan demonstrasi. Data penelitian yang terkumpul digunakan analisis uji $t$-test.

Berdasarkan hasil t-test, dihasilkan bahwa $t_{\text {hitung }}=2,947$ dan $t_{\text {tabel }}=1,68$ dengan taraf nyata $5 \%$ Karena $t_{\text {hitung }}>t_{\text {tabel }}$ maka data tersebut signifikan. Sedangkan untuk uji hipotesis pihak kanan dibandingkan dengan KKM diperoleh $t_{\text {hitung }}=9,2876$ dan $t_{\text {tabel }}=1,714$ maka penggunaan lingkungan sebagai sumber belajar dapat mencapai KKM yang telah ditentukan yaitu 70. Dengan demikian pembelajaran IPA menggunakan lingkungan sebagai sumber belajar efektif terhadap hasil belajar siswa Kelas VII SMP N 2 Pringapus Kabupaten Semarang pada mata pelajaran IPA pokok bahasan.
\end{abstract}

Kata Kunci: Pemanfaatan lingkungan, pemahaman konsep ekosistem 


\section{LATAR BELAKANG}

Pendidikan adalah usaha sadar dan terencana untuk menjadikan suasana belajar dan proses pembelajaran agar peserta didik dapat secara aktif mengembangkan potensi dirinya untuk memiliki kekuatan spiritual, keagamaan, pengendalian diri, kepribadian, kecerdasan, akhlak mulia serta keterampilan yang diperlukan dirinya, masyarakat, bangsa dan negara. ${ }^{1}$

Belajar dan mengajar merupakan dua konsep yang tidak bisa dipisahkan satu sama lain, dua konsep tersebut menjadi terpadu dalam suatu kegiatan mana kala terjadi interaksi guru dengan peserta didik, peserta didik dengan peserta didik, pada saat pengajaran itu berlangsung. Inilah makna belajar dan mengajar sebagai suatu proses interaksi guru dengan peserta didik sebagai makna utama proses pembelajaran yang memegang peranan penting untuk mencapai tujuan pengajaran yang efektif. $^{2}$ Keberhasilan pendidikan formal akan banyak ditentukan oleh keberhasilan pelaksanaan belajar mengajar yang merupakan perpaduan antara kegiatan guru dengan kegiatan peserta didik. Keberhasilan pelaksanaan tersebut tidak lepas dari keseluruhan sistem pendidikan untuk meningkatkan kualitas kegiatan belajar mengajar. Dalam hal ini banyak upaya yang bisa dilakukan antara lain dengan meningkatkan pemahaman pendidik terhadap kegiatan belajar yang inovatif.

Pembelajaran Dengan pemanfaatan alam anak didik tidak hanya mengenal materi IPA sebatas mengenal fakta-fakta saja tetapi anak didik berkesempatan untuk mengadakan suatu aplikasi pengetahuan untuk mengadakan pembaharuan konsep, Lebih dari itu anak didik memahami betul materi yang telah dipelajari dan dapat memecahkan masalah yang dihadapi dengan metode ilmiah. Oleh karena itu dalam pembelajaran IPA seorang guru dituntut untuk dapat mengajak anak didiknya untuk memanfaatkan alam atau lingkungan sekitar.

Dari hasil wawancara peserta didik kelas VII SMPN 2 Pringapus Kabupaten Semarang bahwa selama ini proses pembelajaran IPA masih sering menggunakan metode pembelajaran konvensional (ceramah). Hal ini menyebabkan peserta didik jenuh (bosan) dan kurang aktif dalam proses pembelajaran. Agar pemahaman

${ }^{1}$ Depdiknas, UU RI No. 20 Tahun 2003, (Jakarta: Depdiknas, 2003), cet 1, hlm 22

2 Nana Sudjana, Dasar-Dasar Proses Belajar Mengajar, (Bandung: Sinar Baru Algesindo, 1995), Cet. 3, hlm. 28. 
peserta didik terhadap materi sumber daya alam mengalami peningkatan dan kegiatan belajar mengajar berjalan lebih efektif, maka salah satu alternatif yang diambil adalah menggunakan lingkungan sebagai sumber belajar yang ada di sekitar lokasi sekolah SMP N 2 Pringapus Kabupaten Semarang. Dilingkungan sekolah tersebut terdapat alam yang dapat dimanfaatkan dalam pembelajaran sumber daya alam.

Berdasarkan uraian di atas yang merupakan alasan mendasar dari keinginan peneliti, sehingga tertarik untuk mengadakan penelitian di SMP N Pringapus Kabupaten Semarang dengan judul: efektivitas pembelajaran IPA menggunakan lingkungan sebagai sumber belajar terhadap hasil belajar siswa Kelas VII SMPN 2 Prinagpus Kabupaten Semarang pada materi pokok ekosistem.

Apakah pembelajaran IPA menggunakan lingkungan sebagai sumber belajar efektif terhadap hasil belajar siswa Kelas VII SMP N 2 Priangapus Kabupaten Semarang pada materi Ekosistem. 


\section{KERANGKA TEORI}

\section{Efektivitas}

Mengetahui efektif atau tidaknya pemanfaatan lingkungan sebagai sumber belajar ditunjukkan dengan adanya perbedaan hasil belajar peserta didik antara kelompok yang diberi perlakuan dengan menggunakan lingkungan sebagai sumber belajar dari pada kelompok yang tidak diberi perlakuan.

\section{Belajar}

\section{Pengertian Belajar}

Pembelajaran IPA merupakan upaya guru dalam membelajarkan siswa melalui penerapan sebagai model pembelajaran, model belajar yang dipandang cocok untuk anak indonesia adalah belajar melalui pengalaman langsung (learning by doing). ${ }^{3}$

\section{Hasil Belajar}

Hasil belajar IPA adalah proses yang dilakukan manusia untuk mendapatkan beraneka ragam pengalaman yang berpengaruh dalam proses prestasi belajar yang diperoleh peserta didik setelah melalui proses belajar dalam ilmu IPA.

\section{Lingkungan}

Lingkungan yang berada disekitar kita baik di sekolah maupun di luar sekolah dapat dijadikan sumber belajar. ${ }^{4}$

Disamping itu lingkungan luar sekolah juga dapat digunakan sebagai sumber belajar baik berupa hewan, manusia ataupun masyarakat, tumbuh-tumbuhan, ataupun sumber daya alam lainnya. ${ }^{5}$

\section{METODE PENELITIAN}

\section{Metode Penelitian}

Bentuk eksperimen dalam penelitian ini adalah true experiment design (eksperimen yang betul-betul) bentuk posttest control design. ${ }^{6}$ Dalam bentuk ini

\footnotetext{
3 Nana Djumhana, Pembelajaran Ilmu Pengetahuan Alam, (Jakarta: Direktorat Jenderal Pendidikan Islam Departemen Agama RI, 2009), hlm 2

${ }^{4}$ Usman, M- Asnawir. Media Pembelajaran, (Jakarta, Ciputat Pers,2002), Hal 108

${ }^{5}$ Usman, M- Asnawir. Media Pembelajaran, (Jakarta, Ciputat Pers,2002), Hal 109
} 
terdapat dua kelompok yaitu kelompok pertama diberi perlakuan (X) disebut kelompok eksperimen dan kelompok yang tidak diberi perlakuan disebut kelompok kontrol

\section{Populasi Penelitian}

Populasi pada penelitian ini adalah seluruh peserta didik kelas VII SMPN 2 Kabupaten Semarang yang terdiri dari dua kelas yaitu kelas VII A dan VII C. Dimana kelas VII A berjumlah 34 peserta didik dan kelas VII C berjumlah 32 peserta didik.

\section{Desain Penelitian}

Rancangan penelitian yang digunakan adalah: posttest control group design.

Tabel 3.1 Desain Penelitian

\begin{tabular}{|l|l|l|c|}
\hline \multicolumn{1}{|c|}{ Kelompok } & Pretest & Variabel & Postest \\
\hline Kelas eksperimen & $\mathrm{O}_{1}$ & $\mathrm{X}$ & $\mathrm{O}_{2}$ \\
\hline Kelas control & $\mathrm{O}_{3}$ & & $\mathrm{O}_{4}$ \\
\hline
\end{tabular}

Keterangan:

$\mathrm{O}_{1} \quad=$ Nilai pretest yang diberi perlakuan .

O2 = Nilai posttest yang diberi perlakuan.

$\mathrm{X}=$ = Perlakuan (memanfa'atkan laboratorium alam).

O3 = Nilai pretest yang tidak diberi perlakuan

O4 = Nilai posttest yang tidak diberi perlakuan.

\section{Teknik Pengumpulan Data}

1. Tes

Tes dipakai untuk mengukur ada tidaknya serta besarnya kemampuan objek yang diteliti. Instrumen yang berupa tes dapat digunakan untuk mengukur kemampuan dasar dan pencapaian atau prestasi. $^{7}$

${ }^{6}$ Sugiyono, Metode Penelitian Pendidikan (Pendekatan Kuantitatif, Kualitatif, R\&D),hlm 112113.

${ }^{7}$ Sugiyono, Metode Penelitian Pendidikan . Hlm.223 


\section{Observasi}

Metode observasi adalah metode yang digunakan melalui pengamatan yang meliputi kegiatan pemusatan perhatian terhadap suatu obyek dengan menggunakan keseluruhan alat indera. ${ }^{8}$

\section{Dokumentasi}

Dokumentasi digunakan untuk memperoleh data nama-nama peserta didik yang akan menjadi sampel dalam penelitian, serta untuk memperoleh data nilai ulangan harian pada materi sebelumnya.

\section{HASIL PENELITIAN DAN PEMBAHASAN}

\section{Data Hasil Penelitian}

Kegiatan penelitian dilaksanakan pada tanggal 5 September 2012 sampai 25 September 2012 di SMP N 2 Pringapus Kabupaten Semarang. Kelas VII A merupakan kelas eksperimen dengan jumlah peserta didik 34 anak dan VII C merupakan kelas kontrol dengan jumlah peserta didik 32 anak. Sebelum diberi perlakuan, kedua kelompok dipastikan berangkat dari kemampuan yang seimbang. Berikut ini adalah analisis butir soal hasil uji coba instrumen tes meliputi:

1. Analisis Tahap Awal

a. Uji Normalitas nilai awal kelas kontrol dan eksperimen

Berdasarkan perhitungan dari nilai hasil ulangan pada bab sebelum sumber daya alam maka diperoleh hasil perhitungan normalitas dan homogenitas masing-masing kelompok.

Tabel 4.1. Daftar distribusi frekuensi nilai awal kelas kontrol (VII C)

\begin{tabular}{|c|c|c|c|}
\hline No. & $\begin{array}{l}\text { Interval } \\
\text { Kelas }\end{array}$ & Frekuensi & $\begin{array}{c}\text { Frekuensi } \\
\text { relatif (\%) }\end{array}$ \\
\hline 1 & $36-42$ & 2 & 9,52 \\
\hline 2 & $43-49$ & 2 & 9,52 \\
\hline
\end{tabular}

${ }^{8}$ Amirul Hadi dan Haryanto, Metodologi Penelitian Pendidikan, (Bandung: PustakaSetia, 2005), hlm. 1149. 


\begin{tabular}{|l|c|c|c|}
\hline 3 & $50-56$ & 6 & 28,57 \\
\hline 4 & $57-63$ & 3 & 14,29 \\
\hline 5 & $64-70$ & 5 & 23,81 \\
\hline 6 & $71-77$ & 3 & 14,29 \\
\hline & Jumlah & 21 & 100 \\
\hline
\end{tabular}

Tabel 4.2. Daftar distribusi frekuensi nilai awal kelas eksperimen (VII C)

\begin{tabular}{|l|c|c|c|}
\hline No. & $\begin{array}{l}\text { Interval } \\
\text { Kelas }\end{array}$ & Frekuensi & $\begin{array}{c}\text { Frekuensi relatif } \\
\text { (\%) }\end{array}$ \\
\hline 1 & $36-43$ & 2 & 8,70 \\
\hline 2 & $44-51$ & 3 & 13,04 \\
\hline 3 & $52-59$ & 5 & 21,74 \\
\hline 4 & $60-67$ & 4 & 17,39 \\
\hline 5 & $68-75$ & 3 & 13,04 \\
\hline 6 & $76-83$ & 6 & 26,09 \\
\hline & Jumlah & 23 & 100 \\
\hline
\end{tabular}

Dengan kriteria pengujian, Ho ditolak jika $\chi^{2}$ hitung $\geq \chi^{2}$ tabel untuk taraf nyata $\alpha=0.05$ dan $\mathrm{dk}=\mathrm{k}-3$ dan Ho terima jika $\chi^{2}$ hitung $<\chi_{\text {tabel. Berikut ini }}^{2}$ disajikan hasil perhitungan uji normalitas data nilai awal.

Tabel 4.3 Daftar chi kuadrat data nilai awal

\begin{tabular}{|c|c|c|c|c|c|}
\hline No & Kelas & Kemampuan & $\chi^{2}$ hitung & $\chi^{2}$ tabel & keterangan \\
\hline 1 & Eksperimen & Nilai awal & 5,993 & 7.81 & Normal \\
\hline 2 & Kontrol & Nilai awal & 3,100 & 7.81 & Normal \\
\hline
\end{tabular}


b. Uji kesamaan rata-rata (homogenitas) nilai awal kelas kontrol dan eksperimen Untuk mencari homogenitas data awal dari kelompok kontrol dan eksperimen, digunakan rumus:

$$
F_{\text {hitung }}=\frac{\text { varians terbesar }}{\text { varians terkecil }}
$$

Hipotesis yang diuji adalah:

Ho = varians homogen, $\sigma_{1}^{2}=\sigma_{2}^{2}$

$\mathrm{Ha}=$ varians tidak homogen, $\sigma_{1}^{2} \neq \sigma_{2}^{2}$

Dengan kriteria pengujian, Ho diterima jika $F_{\text {hitung }}<F_{\text {tabel }}$ untuk taraf nyata $\alpha$

$=0.05 \mathrm{dan} \mathrm{dk}=\mathrm{k}-1$. Berikut disajikan hasil perhitungan uji homogenitas data nilai awal.

Tabel 4.4. Daftar Uji homogenitas data nilai awal

\begin{tabular}{|c|c|c|c|c|c|c|c|}
\hline No & Kelas & Kemampuan & Varian & $\mathrm{n}$ & $F_{\text {hitung }}$ & $F_{\text {tabel }}$ & Kriteria \\
\hline 1 & Eks & Nilai awal & 170.06 & 23 & \multirow{2}{*}{1.490} & 2.102 & Homogen \\
\hline 2 & Kont & Nilai awal & 114.13 & 21 & & & \\
\hline
\end{tabular}

\section{Analisis Tahap Akhir}

a. Uji normalitas nilai akhir (post test) kelas eksperimen dan kontrol.

Data nilai ulangan kelas eksperimen diperoleh dari data nilai ulangan pada materi pokok sumber daya alam setelah mendapat perlakuan. Pada kelas VII A setelah diberi perlakuan dengan menggunakan lingkungan sebagai sumber belajar, diperoleh data nilai tertinggi $=100$ dan nilai terendah 68 , rentang $(R)=32$, banyaknya kelas yang diambil 6 kelas, panjang interval kelas 6, dari perhitungan $\sum\left(f_{i} x_{i}\right)=1915.5, \sum\left(f_{i} x_{i}^{2}\right)=161206$, sehingga rata-rata yang diperoleh $(\bar{x})=83,28$ dengan simpangan baku 8,73. 
Tabel 4.8.

Daftar distribusi frekuensi dari data nilai ulangan kelas eksperimen

\begin{tabular}{|c|c|c|c|}
\hline No & Interval & $\begin{array}{c}\text { Frekuensi } \\
\text { Absolut }\end{array}$ & $\begin{array}{c}\text { Frekuensi Relatif } \\
\text { (\%) }\end{array}$ \\
\hline 1 & $68-73$ & 4 & 17,39 \\
\hline 2 & $74-79$ & 4 & 17,39 \\
\hline 3 & $80-85$ & 5 & 21,74 \\
\hline 4 & $86-91$ & 6 & 26,09 \\
\hline 5 & $92-97$ & 3 & 13,04 \\
\hline 6 & $98-103$ & 1 & 4,35 \\
\hline
\end{tabular}

Sedangkan pada kelas VII B setelah diberi perlakuan dengan menggunakan pembelajaran konvensional diperoleh data nilai tertinggi $=92$ dan nilai terendah 52 , rentang $(R)=40$, banyaknya kelas yang diambil 6 kelas, panjang interval kelas 7, dari perhitungan $\sum\left(f_{i} x_{i}\right)=1554, \sum\left(f_{i} x_{i}^{2}\right)=116970$, sehingga rata-rata yang diperoleh $(\bar{x})=74,00$ dengan simpangan baku 9,93

Tabel 4.9.

Daftar distribusi frekuensi dari data nilai ulangan kelas kontrol

\begin{tabular}{|c|c|c|c|}
\hline No & Interval & $\begin{array}{c}\text { Frekuensi } \\
\text { Absolut }\end{array}$ & $\begin{array}{c}\text { Frekuensi Relatif } \\
\text { (\%) }\end{array}$ \\
\hline 1 & $52-58$ & 2 & 9,52 \\
\hline 2 & $59-65$ & 2 & 9,52 \\
\hline 3 & $66-72$ & 4 & 19,05 \\
\hline 4 & $73-79$ & 7 & 33,33 \\
\hline 5 & $80-86$ & 4 & 19,05 \\
\hline 6 & $87-93$ & 2 & 9,52 \\
\hline
\end{tabular}


Dengan kriteria pengujian, Ho ditolak jika $\chi^{2}$ hitung $\geq \chi^{2}$ tabel untuk taraf nyata $\alpha=0.05$ dan dk $=$ k-3 dan Ho terima jika $\chi^{2}$ hitung $<\chi^{2}$ tabel. Berikut disajikan hasil perhitungan uji normalitas data nilai akhir.

Tabel 4.10 Daftar Chi Kuadrat Data Nilai Akhir

\begin{tabular}{|c|c|c|c|c|c|}
\hline No & Kelas & Kemampuan & $\chi^{2}$ hitung & $\chi^{2}$ tabel & Keterangan \\
\hline 1 & Eksperimen & Nilai akhir & 1.896 & 7,81 & Normal \\
\hline 2 & Kontrol & Nilai akhir & 1,892 & 7,81 & Normal \\
\hline
\end{tabular}

b. Uji kesamaan rata-rata (homogenitas) nilai akhir kelas eksperimen dan kontrol

$$
\begin{aligned}
& \mathrm{Ho}=\sigma_{1}{ }^{2}=\sigma_{2}{ }^{2} \\
& \mathrm{Ha}=\sigma_{1}{ }^{2} \neq \sigma_{2}{ }^{2}
\end{aligned}
$$

Dengan kriteria pengujian, Ho ditolak jika $F_{\text {hitung }}<F_{\text {tabel }}$ untuk taraf nyata $\alpha=0.05$ dan $\mathrm{dk}=\mathrm{k}-1$ maka data homogen. Di bawah ini disajikan hasil perhitungan uji homogenitas nilai akhir sebagai berikut.

Tabel 4.11. Daftar Uji Homogenitas Data Nilai Akhir

\begin{tabular}{|c|c|c|c|c|c|c|c|}
\hline No & Kelas & Kemampuan & Varian & $\mathrm{n}$ & $F_{\text {hitung }}$ & $F_{\text {tabel }}$ & Kriteria \\
\hline 1 & Eks & Nilai akhir & 81,075 & 23 & \multirow{2}{*}{1.177} & 2,071 & Homogen \\
\hline 2 & Kntrl & Nilai akhir & 95,390 & 21 & & & \\
\hline
\end{tabular}

c. Uji perbedaan rata-rata (uji $t$ ) kelas eksperimen dan kontrol

Menurut perhitungan data hasil belajar atau data nilai akhir menunjukkan bahwa hasil perhitungan pada kemampuan akhir Kelas eksperimen setelah mendapat perlakuan dengan pembelajaran menggunakan lingkungan sebagai sumber belajar diperoleh rata-rata 82,43 dan setandart deviansi(SD) adalah 9.00, sedangkan untuk kelas kontrol dengan setelah mendapat perlakuan dengan menggunakan pembelajaran konvensional diperoleh rata-rata 74.10 dan setandart deviansi(SD) adalah 9,77 . 
Dari hasil perhitungan t-test diperoleh $t_{\text {hitung }}=2,947$ dikonsultasikan dengan $t_{\text {tabel }}$ pada $\alpha=5 \% d k=\left(n_{1}+n_{2}-2\right)=42$ diperoleh $t_{\text {tabel }}=1,68 \mathrm{hal}$ ini menunjukkan bahwa $t_{\text {hitung }}>t_{\text {tabel }}$ sehingga Ho di tolak dan Ha diterima. Artinya antara Kelas eksperimen dan kelas kontrol memiliki rata-rata hasil belajar materi sumber daya alam yang tidak sama atau berbeda secara signifikan.

d. Uji satu pihak kelas eksperimen (uji pihak kanan)

Uji satu pihak kelas eksperimen ini untuk mengetahui apakah hasil belajar kelas eksperimen sudah mencapai KKM atau belum. Uji ini menggunakan rumus one sample $t$ - test diperoleh data sebagai berikut:

$\mathrm{H}_{0}: \mu_{1}<7$ (KKM)

$\mathrm{H}_{1}: \mu_{1} \geq 70$ (KKM)

$\mathrm{H}_{0}$ akan ditolak jika $t_{\text {hitumg }} \geq t_{(\alpha, n-1)}$ dengan:

$\mu_{1} \quad=$ rata-rata hasil belajar peserta didik kelas VII A yang diajar dengan menggunakan lingkungan sebagai sumber belajar .

$\mathrm{KKM}=$ Kriteria Ketuntasan Minimal

Tabel 4.12 Hasil analisis uji pihak kanan.

\begin{tabular}{|c|c|}
\hline Sumber variasi & Papan Garis-Garis Sejajar \\
\hline Jumlah nilai & 1896 \\
\hline $\mathrm{N}$ & 23 \\
\hline Rata-rata $(\bar{X})$ & 82,43 \\
\hline Varians $\left(\mathrm{s}^{2}\right)$ & 81,08 \\
\hline Standar Deviasi $(\mathrm{s})$ & 9,00 \\
\hline$t_{\text {hitung }}$ & 9,2879 \\
\hline$t_{\text {tabel }(\alpha=5 \%)}$ & 1,714 \\
\hline
\end{tabular}

Diperoleh $t_{\text {hitumg }}<t_{\text {tabel }}$ sesehingga $H_{0}$ ditolak. Artinya dengan penggunaan lingkungan sebagai sumber belajar dapat mencapai KKM. 


\section{Pembahasan}

1. Skor Kemampuan Awal (Nilai Awal)

Sebelum penelitian dilakukan perlu diketahui terlebih dahulu kemampuan awal kedua sampel penelitian apakah sama atau tidak. Oleh karena itu peneliti menggunakan nilai sebelum materi sumber daya alam, yang kemudian data tersebut peneliti sebut dengan data nilai awal. Berdasarkan perhitungan uji normalitas dan uji varians pada data nilai awal dari kedua kelas adalah berdistribusi normal dan homogen. Hal ini dapat dikatakan bahwa kondisi kemampuan awal peserta didik sebelum dikenai perlakuan dengan menggunakan pembelajaran menggunakan lingkungan sebagai sumber belajar dan pembelajaran konvensional memiliki kemampuan yang setara atau sama.

2. Skor Kemampuan Akhir ( Nilai Akhir)

Setelah penelitian dilakukan maka akan dilakukan analisis hipotesis data hasil belajar kelas eksperimen dan kelas kontrol pada materi sumber daya alam yang sudah mendapatkan perlakuan yang berbeda. Berdasarkan perhitungan uji normalitas dan uji varians pada hasil belajar dari kedua kelas eksperimen setelah diberi perlakuan berbeda adalah berdistribusi normal dan homogen. Sehingga dapat dilanjutkan pada pengujian selanjutnya yaitu uji kesamaan dua rata-rata hasil belajar kelas eksperimen.

Selanjutnya pada pengujian kesamaan dua rata-rata pada hasil belajar dari kedua kelas eksperimen setelah diberi perlakuan yang berbeda, diperoleh $t_{\text {hitung }}=2,947$ dan $t_{\text {tabel }}$ pada $\alpha=5 \% d k=\left(n_{1}+n_{2}-2\right)$ diperoleh 1,68. Oleh karena $t_{\text {hitung }}>t_{\text {tabel }}$, maka hasil pembelajaran yang menggunakan lingkungan sebagai sumber belajar pada materi pokok sumber daya alam dengan hasil pembelajaran yang menggunakan pembelajaran konvensional berbeda secara nyata. Hal ini sesuai dengan pendapat Drs. M. Basyiruddin Usman bahwa penggunaan lingkungan dapat menjadi sumber belajar yang efektif. Selain itu dapat dilihat pula pada rata-rata hasil belajar kelas eksperimen setelah menggunakan pembelajaran yang menggunakan lingkungan sebagai sumber belajar pada materi pokok ekosistem adalah 82,43 dan nilai rata-rata hasil belajar kelas kontrol setelah menggunakan pembelajaran konvensional adalah 
74,10 hal ini berarti bahwa nilai rata-rata yang menggunakan pembelajaran yang menggunakan lingkungan sebagai sumber belajar lebih tinggi dari pada nilai rata-rata pembelajaran yang menggunakan pembelajaran konvensional. Sedangkan untuk uji hipotesis pihak kanan dibandingkan dengan KKM diperoleh $t_{\text {hitung }}=9,2876$ dan $t_{\text {tabel }}=1,714$ maka penggunaan lingkungan sebagai sumber belajar dapat mencapai KKM yang telah ditentukan yaitu 70 .

Dari hasil uraian di atas dapat disimpulkan bahwa hasil belajar peserta didik dengan menggunakan pembelajaran yang menggunakan lingkungan sebagai sumber belajar lebih baik dari hasil belajar peserta didik dengan menggunakan pembelajaran konvensional pada materi pokok ekosistem peserta didik kelas VII SMPN 2 Pringapus Kabupaten Semarang tahun ajaran 2012-2013. Sehingga pembelajaran yang menggunakan lingkungan sebagai sumber belajar efektif terhadap hasil belajar peserta didik pada materi pokok ekosistem peserta didik kelas VII SMPN 2 Pringapus Kabupaten Semarang tahun ajaran 2012-2013. 


\section{PENUTUP}

\section{Simpulan}

Dari pembahasan yang telah dilakukan dapat disimpulkan bahwa menggunakan lingkungan sebagai sumber belajar efektif terhadap hasil belajar peserta didik kelas VII pada materi ekosistem di SMPN 2 Prinagpus Kabupaten Semarang. Rata-rata nilai kelompok eksperimen lebih tinggi daripada kelompok kontrol. Kelas eksperimen mempunyai rata-rata nilai posttest 82,43 sedangkan kelas kontrol mempunyai nilai rata-rata 74,10 .Berdasarkan hasil pengujian hipotesis nilai akhir antara kelas eksperimen dan kontrol dengan menggunakan uji perbedaan ratarata diperoleh $t_{\text {hitung }}=2,947$ dan $t_{\text {tabel }}=1,68$. Karena $t_{\text {hitung }}>t_{\text {tabel }}$ maka Ho ditolak.

\section{Saran}

Untuk meningkatkan kualitas pembelajaran, khususnya mata pelajaran IPA, ada beberapa saran yang untuk diperhatikan dalam pembelajaran IPA, diantaranya:

1. Guru mata pelajaran IPA hendaknya selalu melakukan perbaikan-perbaikan dan meningkatkan kualitas pembelajaran dengan menggunakan model pembelajaran sesuai dengan kondisi/ materi yang disampaikan.

2. Proses pembelajaran materi sumber daya alam hendaknya disampaikan secara menyenangkan dengan berbagai metode, strategi dan media yang sesuai. Hal ini untuk menumbuhkan motivasi peserta didik dalam proses belajar mengajar 


\section{DAFTAR PUSTAKA}

Agus Suprijono, Cooperatif Learning: Teori dan Aplikasi PAIKEM, Yogyakarta: Pustaka Belajar, 2010

Amin Suyitno, CTL dan Model Pembelajaran Inovatif serta Penerapannya pada SD/SMP Cl-BI, Semarang, Bahan Ajar ini digunakan untuk keperluan pelatihan guru-guru Matematika SD/SMP Cl-BI di Salatiga Provinsi Jawa Tengah, 25 Februari 2010.

Amirul Hadi dan Haryanto, Metodologi Penelitian Pendidikan, Bandung: PustakaSetia, 2000

Anas Sudijono, Pengantar Evaluasi Pendidikan, Jakarta: Rajawali Press, 2009

Baharudin, Teori Belajar Dan Pembelajaran, Jogjakarta, Ar - Ruzz Media, 2010

Baharudin, Teori Belajar Dan Pembelajaran, Jogjakarta, Ar - Ruzz Media, 2010

Depdiknas, Kamus Besar Bahasa Indonesia, Jakarta: Balai Pustaka, 2005

Depdiknas, UU RI No. 20 Tahun 2003, Jakarta: Depdiknas, 2003

Dwi Yulianti, Bermain Sambil Belajar Sains, Jakarta: PT Indeks, 2010Engkoswara, Metodologi Pengajaran, Jakarta, Bina Aksara, 1984

Muhaimin, Paradigma Pendidikan Islam, Upaya Mengefektifkan Pendidikan Agama Islam Di Sekolah, Bandung: Remaja Rosda Karya, 2001

Moh Amin, Buku Pedoman Laboratorium dan Petunjuk Praktikum Pendidikan IPA Umum, Jakarta, Departemen Pendidikan Dan Kebudayaan, 1988 
Mulyasa, Manajemen Berbasis Sekolah Konsep, Strategi, Dan Implementasi, Bandung, PT Remaja Rosdakarya, 2007

Nana Djumhana, Pembelajaran Ilmu Pengetahuan Alam, Jakarta: Direktorat Jenderal Pendidikan Islam Departemen Agama RI, 2009

Nana Rukmana, Model Manajemen Pendidikan Berbasis Kemitraan, Jakarta:

ALFABETA, 2006

Nana Sudjana, Dasar-Dasar Proses Belajar Mengajar, Bandung: Sinar Baru Algesindo, 1995

Nana Sudjana, Media Pengajaran, Bandung: Sinar Baru, 2005

Riduwan, Dasar-Dasar Statistika, Bandung: Alfabeta, 2008

Rita Maryana, Pengelolaan lingkungan belajar, Jakarta: Kencana Prenada Media Group, 2010

S. Rositawaty, Senang belajar Ilmu Pengetahuan Alam 4: Jakarta: Pusat Perbukuan, Departemen Pendidikan Nasional, 2008

Sudiyono, Ilmu Pendidikan Islam, Jilid 1, Jakarta : PT. Asdi Mahasatya, 2009

Sudjana, Metode Statistika, Bandung: Tarsito, 2005

Sugiyono, Metode Penelitian Pendidikan (Pendekatan Kuantitatif, Kualitatif, R\&D), Bandung: Alfabeta, 2008

Suharsimi Arikunto, Prosedur Penelitian Suatu Pendekatan Praktek, Jakarta: Rineka Cipta, 2006

Slameto, Belajar dan Faktor-faktor yang Mempengaruhinya, Jakarta: Rineka Cipta, 2003 
Syaiful Sagala, Konsep dan Makna Pembelajaran, Bandung: Alfabeta, 2003

Udin S. Winataputra, Strategi Belajar Mengajar IPA, Jakarta: Universitas Terbuka,2001

Trianto, Mendesain Model Pembelajaran Inovatif - Progresif: Konsep dan Implementasinya pada Kurikulum Tingkat Satuan Pendidikan (KTSP), Jakarta: Kencana, 2010

Trianto, Model Pembelajaran Terpadu Dalam Teori Dan Praktek, Jakarta:Prestasi Pustaka, 2007

Wina Sanjaya, Stategi Pembelajaran, Jakarta: Kencana, 2007 